\title{
Research Method for the Selection of Building Materials and a Model Proposal
}

\author{
Orkun Alptekin ${ }^{1, *}$, Gulser Celebi ${ }^{2}$ \\ ${ }^{1}$ Engineering \& Architecture Faculty, Eskisehir Osmangazi University, Eskisehir, Turkey \\ ${ }^{2}$ Architecture Faculty, Cankaya University, Ankara, Turkey
}

Copyright $\bigcirc 2018$ by authors, all rights reserved. Authors agree that this article remains permanently open access under the terms of the Creative Commons Attribution License 4.0 International License

\begin{abstract}
In environmentally-friendly architectural approaches, the importance of the building materials in the construction of buildings is undeniable. As with all products, the environmental effect of building materials is defined according to many environmental impact classes, and the values of such classes expressed in line with various criteria. In an environmentally-friendly architectural approach, criteria, such as embodied energy and local resource reserves play a significant role in the selection of materials. Therefore, a mixed material selection method that allows the comparison of different criteria and that lists them as part of a multiple-criteria decision-making method is indispensable when deciding upon the most appropriate materials. This study proposes a material selection model that is based on the Life Cycle Assessment method, and which can be used by all architects and disciplines, particularly in the construction sector. This study tests the model to support its validity.
\end{abstract} Keywords Multiple-criteria Decision-making
Methods, Life Cycle Assessment, Building Materials,
Embodied Energy

\section{Introduction}

The increasing need for the efficient use of resources has resulted in increased efforts to improve and measure the environmental performance of buildings in many countries This has led to a major problem for architects in the selection of appropriate materials according to different environmental impact classes. Studies into the life cycle of buildings have found out that the embodied energy and potential environmental impacts of the materials used in construction play a significant role in determining the environmental performance of buildings [1-12]. In analyses of the manufacturing process and the transportation of building materials, it has been shown that embodied energy constitutes a significant portion of the energy used throughout the life cycle of the building $[1,2$,
7, 13, 14]. For instance, a study conducted by Verbeeck and Hens, which compared the embodied and primary energies (i.e. energy used for heating, cooling and similar functions during the use of the structure) in residential buildings found that the initial embodied energy of a 30 -year-old structure constitutes $1 / 4$ of the total energy used, and that this ratio increases, if the building is insulated [2]. Other studies have confirmed this finding to varying degrees, suggesting that embodied energy accounts for 45 [13, 15, 16], 40 [17,18], 43 [19], 60 [20], 25 [21] and $65 \%$ [22] of the energy used throughout the life of a 50-year-old structure. A similar study conducted by Kim and Ringdon calculated the amount of energy required in cases with and without thermal insulation during the use of a building with a floor area of $150 \mathrm{~m} 2$ for 30 years and compared the embodied energy and primary energy values. The study found that embodied energy corresponds to $1 / 8$ of the total energy used by an uninsulated building and that this ratio rises to $1 / 3$ when the building is insulated [14]. Chang et al. found that $1 / 6$ of the total energy used in China in 2007 was used as embodied energy in the manufacture of materials for the construction sector [23]. Chwieduk also underlined the importance of embodied energy in buildings and noted that the measures taken to improve the environmental performance of buildings for the period of use would be insufficient if the embodied energy of the materials that make up the structure were not considered [24]. Moncaster and Symons stress the importance of selecting building materials in the early design phase for the life cycle of a building and suggest a model for the calculation of the environmental performance of a building in accordance with UK standards [25].

There have been many studies that emphasized the importance of embodied energy in the environmental performance of buildings, and it has been stated that the insufficiencies of existing assessment tools and methods point to the need for a common method for the assessment of material production and transportation before construction [17, 26 - 36]. The results of other studies indicate that the embodied energy in low-energy buildings constitutes a significant portion of the energy used by a 
building throughout its lifecycle. After using a building for a period of 20-25 years, on average, the embodied energy and primary energy values become equal $[1,2,7,14]$. These studies have also underlined the importance of embodied energy in efforts to prolong the service life of buildings by making them energy-efficient. As the service life of a building is prolonged, the significance of the environmental impacts during its use increases. The environmental impacts related to the renovation, maintenance and repair works carried out during this process are also taken into account [37 - 39]. While the energy used for heating, cooling and lighting can be reduced through various measures, such as the addition of insulating materials, hardware arrangements, throughout the life of a building, embodied energy can be reduced only through the selection of appropriate materials during the design phase, before the construction. The environmental impacts of buildings are not limited only to the amount of energy used, as assessments should be made according to many environmental impact classes, including global warming $(\mathrm{CO} 2)$, human health noncancer $(\mathrm{gC} 7 \mathrm{H} 8)$, human health cancer (gC6H6), acidification $(\mathrm{mgH}+)$, eutrophication $(\mathrm{gN})$, fossil fuel depletion $(\mathrm{Mj})$, water intake (liters), air pollutants (MicroDALYs), smog (gNOx), ozone depletion (gCFG-11), ecological toxicity (g2,4-D) and habitat alteration (T\&E species). Additionally, as standards [40] enter into effect, the calculation of buildings' environmental performances according to environmental impact classes becomes mandatory. In the standard [40], a calculation method is presented that is to be applied to each material and each impact class when calculating a building's environmental performance. The method of calculation based on acidification, as one of the impact classes, is shown in the equation below:

$$
\begin{array}{r}
\text { Acidification }_{\mathrm{b}}=\mathrm{a}_{1 \mathrm{~m}} \mathrm{xA} \mathrm{A}_{\mathrm{a} 1 \mathrm{~m}}+\mathrm{a}_{2 \mathrm{i}} \mathrm{xA} \mathrm{A}_{\mathrm{a} 2 \mathrm{~m}}+\mathrm{a}_{3 \mathrm{i}} \mathrm{xA}_{\mathrm{a} 3 \mathrm{~m}}+\mathrm{a}_{4 \mathrm{i}} \mathrm{xA}_{\mathrm{a} 4 \mathrm{~m}}+\ldots+ \\
\mathrm{a}_{\mathrm{nm}} \mathrm{xA}_{\mathrm{anm}}
\end{array}
$$

Acidification $_{\mathrm{b}}=$ Building's performance for acidification, one of the environmental impact classes.

$\mathrm{a}_{\mathrm{nm}}=$ Amount of the material used in the building

$\mathrm{A}_{\mathrm{anm}}=$ The material's environmental impact value for acidification

According to the calculation method specified in the standard, the selection of a building material that directly affects the building's performance is a process that needs to be considered on the basis of multiple criteria for the material, expressed in different units. A material that has a low environmental impact value in relation to an environmental impact class may have a high environmental impact value in relation to another environmental impact classes. It is clear, in this regard, that the selected material can affect the building's environmental performance positively in one environmental impact class and negatively in another. Considering this, to be able to evaluate alternative materials

that have different impacts in each environmental impact class, first the environmental impact classes and their degree of importance should be defined, based on the priorities of each country. A method in which all environmental impact classes for a given building material are assessed according to their predetermined degree of importance and reduced to a single criterion will bring considerable convenience to the selection of materials. This study proposes such a method.

\section{Materials and Methods}

As emphasized above, in any approach to the selection of materials according to a building's environmental performance, the criteria for selection is very complicated. In this context, it is necessary for the material selection process to be supported by decision-making methods in the design phase so that the environmental performance of the building can be audited. Based on this assumption, this study proposes a material selection model that compares and assesses the environmental impact data of materials and reduces the assessment criteria to a single criterion. In this model, the environmental impacts of materials are assessed based on their environmental impact classes, and materials are listed in ascending order, from the materials with low environmental impacts to the materials with high environmental impacts. The suggested model also defines the basics of a software package that aimed to ease material selection that architects can draw upon when determining a building's environmental performance. In other words, the model construct is considered with a simplified definition, and a flowchart for the suggested model is developed, as shown in Figure 1 [41].

As can be seen in Figure 1, first, the alternative materials are identified, and then, the environmental impact class data of the alternatives is retrieved from a database and listed by degree of importance. Determining the degree of importance makes use of a "factor analysis method", which is a statistical technique that reduces the number of variables to a lower number of basic dimensions, and is used to facilitate an understanding and interpretation of the relationships that exist between numerous variables that are considered to be interrelated. In the next phase of the process, each building material is assessed by "TOPSIS" (Technique for Order Preference by Similarity to Ideal Solution) [42], as a multiple-criteria decision-making method, according to its degree of importance. At the end of the assessment, the material options are listed in ascending order regarding their environmental impact values, reduced to a single criterion. The flowchart of the software and package is shown in Figure 2 [41] below.

The suggested model is tested with a case study. In the first phase of the case study, the objective and scope of the study are defined in line with the Life Cycle Assessment method. In the second phase, the parameters that define the framework of the study are identified. In the following stage, the data collection method is developed, and the 
model to be used in the analysis of the data is tested. The testing of the model makes use of the environmental impact values for the periods of extraction of raw materials and the production of the finishing materials used on the floors of the indoor spaces, and the assessment of material selection is shown with an authentic case. In the final phase of the case study, the assessment results are interpreted, and suggestions are made.

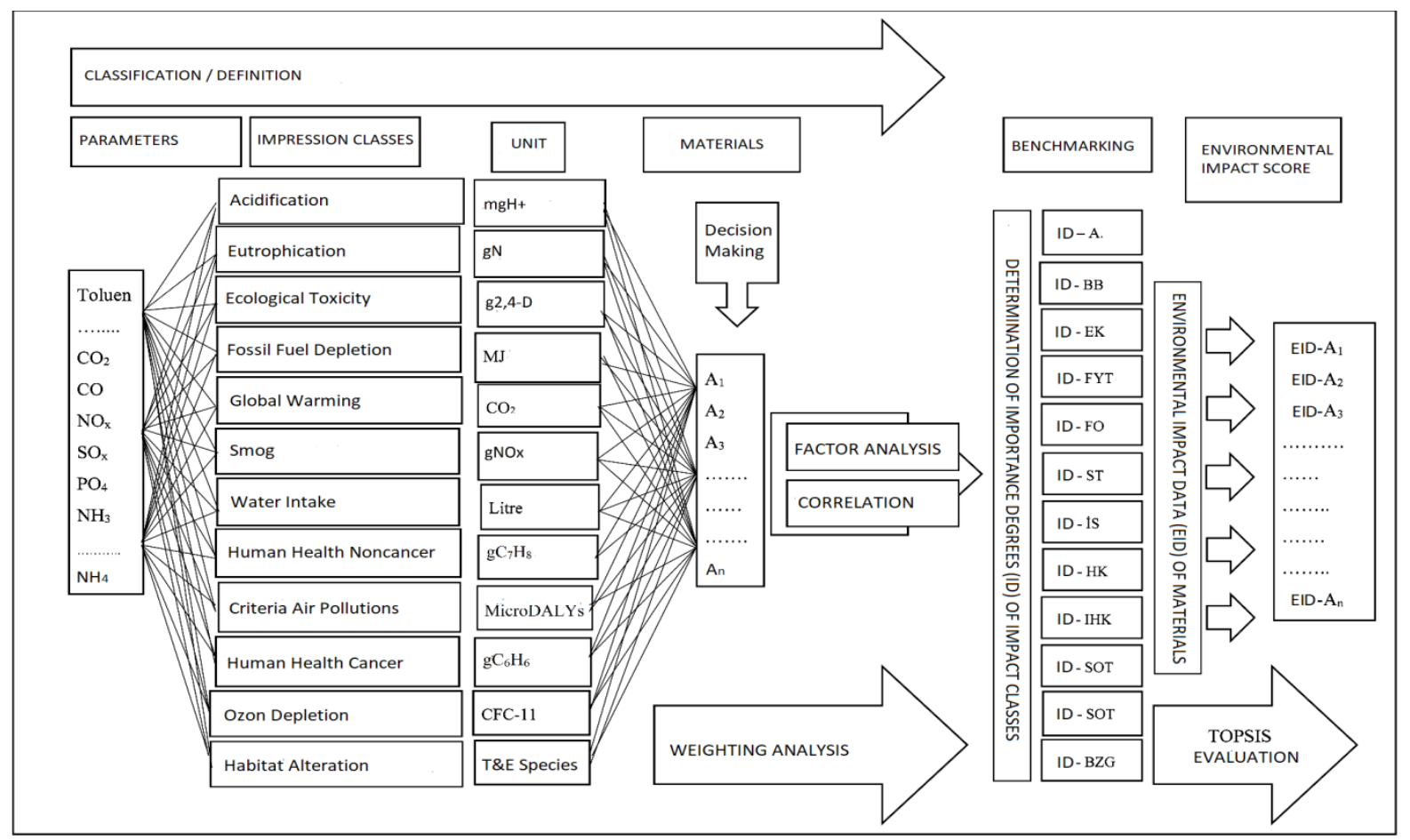

Figure 1. Environmental impact assessment model flowchart [41]

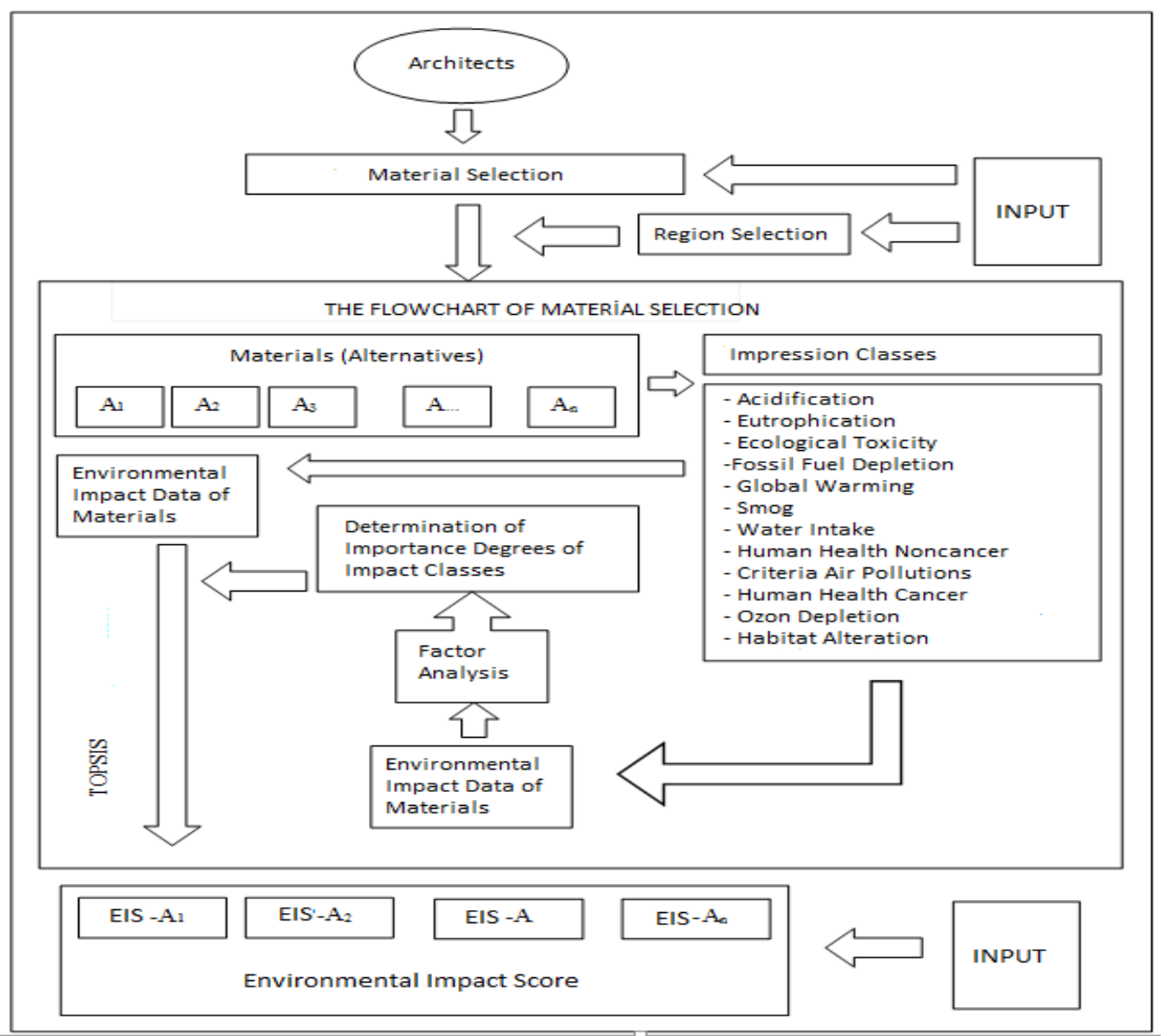

Figure 2. The flowchart of material selection [41] 
The methods employed in the model and the assumptions made can be detailed as follows: First of all, databases and environmental impact classes should be defined individually, considering the main environmental problems faced by each country and region. Turkey currently has no such database. Thus, the environmental impact value data for the periods of extraction of raw materials and the production of materials have been obtained from the database developed by the American National Institute for Standards and Technology [48], in accordance with "ISO 14000 Life Cycle Assessment Standards" [43-47]. The flexibility of the model developed in this study allows it to be used with other databases and for the assessment of different criteria in all phases of the life cycle.

In the developed model, the impacts of building materials on global warming $\left(\mathrm{CO}_{2}\right)$, noncancer aspects of human health $(\mathrm{gC} 7 \mathrm{H} 8)$, development of cancer $(\mathrm{gC} 6 \mathrm{H} 6)$, acidification $(\mathrm{mgH}+)$, eutrophication $(\mathrm{gN})$, fossil fuel depletion $(\mathrm{Mj})$, water intake (liters), air pollutants (MicroDALYs), formation of smog (gNOx), ozone depletion (gCFG-11) and ecological toxicity (g2,4-D) are assessed. For the testing of the model, the values obtained for each material in relation to the criterion habitat alteration (T\&E species) are assumed to be zero.

To list the building materials in ascending order regarding their environmental impact values, reduced to a single criterion, this study uses "TOPSIS", a multiple-criteria decision-making method. First, the degree of importance of the criteria should be determined on the basis of the data obtained from the life cycle assessment software. In determining the degrees of importance, a "factor analysis method" in the form of a multivariable analysis technique is used. As the material options and the environmental impact class data changes, so do the degrees of importance, depending on the correlation of such data. Once the degrees of importance are determined, the environmental impact criteria are assessed together using the TOPSIS method and are reduced to a single criterion for assessment. Comparisons are made on the basis of the ideal condition between the maximum and minimum values that the alternatives may have in relation to certain criteria. After determining the materials to be assessed in this study, the criteria and the method to be employed, an assessment is made in the second phase, and results are obtained.

\section{Testing of the Model and Results}

In the suggested model, the finishing materials that can be used to cover the floor of an indoor space are used as an example. The environmental impacts of linoleum, mosaic, synthetic and wool carpet, artificial marble, vinyl and ceramic flooring materials used as floor coverings in indoor spaces are assessed and arranged in order. Since the environmental impacts of the materials during their production phase are considered, their lifespan is excluded.

In the equation, for ' $\mathrm{a}$ ' values $1 \mathrm{~m}^{2}$ is used as the unit area of each material. For A values, an American database [48] was used, because, no such database exists currently in Turkey, although standard [40] is published. In the study, due to the lack of material alternatives and hence data on materials in the database, floor covering materials were selected. The results obtained from the assessment of each material using equation 1 are given in Table 1 [41] below.

Table 1. Data for the environmental impact of alternatives [41]

\begin{tabular}{|c|c|c|c|c|c|c|c|}
\hline \multirow[b]{2}{*}{ Environmental Impact Classes } & \multicolumn{7}{|c|}{ Material Alternatives } \\
\hline & $\begin{array}{c}\text { A1 } \\
\text { Artificial } \\
\text { Marble }\end{array}$ & $\begin{array}{c}\text { A2 } \\
\text { Linoleum }\end{array}$ & $\begin{array}{c}\text { A3 } \\
\text { Synthetic } \\
\text { Carpet }\end{array}$ & $\begin{array}{c}\text { A4 } \\
\text { Mosaic }\end{array}$ & $\begin{array}{c}\text { A5 } \\
\text { Ceramic }\end{array}$ & $\begin{array}{c}\text { A6 } \\
\text { Vinyl } \\
\text { Flooring }\end{array}$ & $\begin{array}{c}\text { A7 } \\
\text { Wool } \\
\text { Carpet }\end{array}$ \\
\hline Acidification $(\mathrm{mgH}+)$ & 2200.2516 & 654.3764 & 2228.0017 & 1037.3058 & 1110.4098 & 548.1763 & 28819.031 \\
\hline Eutrophication $(\mathrm{gN})$ & 1.2876 & 2.0971 & 4.3518 & 1.8272 & 0.4161 & 0.2047 & 64.8809 \\
\hline Ecologic Toxicity (g2,4-D) & 20.8797 & 7.6544 & 24.8818 & 27.7677 & 7.6958 & 6.0595 & 122.242 \\
\hline Fossil Fuel Depletion (Mj) & 12.243 & 2.5758 & 13.637 & 6.2244 & 3.8316 & 2.4517 & 11.727 \\
\hline Global Warming $\left(\mathrm{CO}_{2}\right)$ & 3893.1757 & 997.6768 & 5027.3043 & 2520.019 & 2423.464 & 1043.3019 & 37551.1443 \\
\hline Formation of $\operatorname{Smog}\left(\mathrm{gNO}_{\mathrm{x}}\right)$ & 29.2652 & 12.3381 & 27.7083 & 17.8689 & 11.9967 & 4.8293 & 453.2015 \\
\hline Water Intake (liter) & 597.8523 & 341.3698 & 256.3601 & 517.3437 & 5.3661 & 6.8356 & 346.7848 \\
\hline Human Health - Cancer $\left(\mathrm{gC}_{6} \mathrm{H}_{6}\right)$ & 124.8114 & 1.0125 & 6.9101 & 10.1877 & 14.5942 & 0.9643 & 8.7713 \\
\hline Human Health- Noncancer $\left(\mathrm{C}_{7} \mathrm{H}_{8}\right)$ & 158025.061 & 2048.6406 & 10804.4428 & 26281.5998 & 65036.6936 & 1937.4582 & 26435.09 \\
\hline Air Pollutants (MicroDALYs) & 0.592 & 0.1405 & 0.6574 & 1.0281 & 0.3141 & 0.1454 & 2.0419 \\
\hline Ozon Depletion (gCFG-11) & 0 & 0 & 0 & 0.0001 & 0 & 0 & 0.0001 \\
\hline
\end{tabular}


When a selection is to be made according to the criteria in Table 1 [41], vinyl flooring can be seen to have the lowest environmental impact value in seven of the 10 criteria and ranks second in the remaining three criteria. However, it is not possible to make a clear decision based only on this, as the criteria's degree of relative importance is not known. Thus, multiple-criteria decision-making methods should be employed to sort the alternatives. To determine the priorities for the criteria, factor analysis is used as an objective method. As a result of the factor analysis, in which interrelated criteria are gathered under factors that are not interrelated, the criteria are gathered under two factors in Table 2 [41] that explain $85.209 \%$ of the total change (sum of explaining of factor 1 and factor 2), with factor 1 explaining $60.804 \%$ and factor 2 explaining $24.406 \%$ of the total change. To determine the priorities of the criteria, the Varimax Method was employed for a factor rotation, as a result of which the factor matrix in Table 2 [41] was obtained.

Table 2. Factor matrix [41]

\begin{tabular}{|c|c|c|}
\hline \multirow{2}{*}{ Environmental Impact Classes } & \multicolumn{2}{|c|}{ Components } \\
\cline { 2 - 3 } & 1 & 2 \\
\hline Acidification & 0.973 & -0.089 \\
\hline Air Pollutants & 0.971 & 0.076 \\
\hline Ecological Toxicity & 0.999 & -0.024 \\
\hline Eutrophication & 0.972 & -0.132 \\
\hline Fossil Fuel Depletion & 0.535 & 0.591 \\
\hline Global Warming & 0.979 & -0.073 \\
\hline Human Health - Cancer & -0.070 & 0.965 \\
\hline Human Health - Noncancer & -0.055 & 0.912 \\
\hline Formation of Smog & 0.974 & -0.095 \\
\hline Water Intake & 0.288 & 0.719 \\
\hline Ozone Depletion & 0.757 & -0.102 \\
\hline
\end{tabular}

Using the factor loads that represent the relationship of each criterion with the two factors, the part of the total change not explained by each factor $(1-0.85209=0.14791)$ was distributed among the factors in proportion to their explanation percentages in such a manner as to make the total percentage of explanation of the two factors equal $100 \%$. Accordingly, the relationships of factor 1 with acidification, air pollutants, ecological toxicity, eutrophication, global warming, the formation of smog and ozone depletion were found to be strong; and the relationships of factor 2 with fossil fuel depletion, carcinogenic impacts, non-cancer human health impacts and water intake were found to be strong. Thus, the degree of importance of factor 1 (0.14791) was distributed to the variables of acidification, air pollutants, ecological toxicity, eutrophication, global warming, the formation of smog and ozone depletion in proportion to their factor loads.

By adding the following value to the explanation percentage of factor $1(60.804 \%=0.060804)$

$0.14791 * 0.60804=0.089935$ and adding the following value to the explanation percentage of factor $2(24.406 \%=0.24406)$

$0.14791 * 0.24406=0.036099$

The adjusted degrees of explanation of the factors were found to be 0.69798 and 0.28016 , respectively. The sum of the factor loads of the variables of acidification, air pollutants, ecological toxicity, eutrophication, global warming, the formation of smog and ozone depletion is 5.868. Accordingly, the degree of importance of the variable acidification was obtained as follows:

$0.69798 * 0.977 / 5.868=0.1162$

Thus, the vector of the degrees of importance calculated for each variable is as follows:

wi $=0.1162,0.1184,0.1167,0.0569,0.1167,0.0836$, $0.0791,0.1164,0.0657,0.0166$

The weighted standard decision matrix was obtained by multiplying each variable by its degree of importance. This matrix is shown in Table 3 [41].

To sort the materials according to the TOPSIS method, the value of each alternative was multiplied by the degree of importance assigned to it in the Factor Analysis, and among the values obtained, the largest was selected as the positive ideal solution, and the smallest was selected as the negative ideal solution. By calculating the distance of each option from the positive and negative ideal solution, the similarity of each option to the ideal solution was found. All of the calculated values are given in Table 4 [41].

As can be seen in Figure 3 [41], vinyl flooring has the highest performance (lowest environmental impact), whereas synthetic carpet has the lowest performance (highest environmental impact). Vinyl flooring is followed by linoleum, artificial marble, wool carpet, ceramic flooring and mosaic flooring. The two groups of materials with similar content, namely vinyl and linoleum, and artificial marble, mosaic and ceramic, have similar environmental impacts. To test the model, an American database was used, and an assessment was made according to the characteristics of this country, as no such database exists currently in Turkey. In this context, polyvinyl chloride (PVC) layer is used in the production of wool carpet, and this adds to the environmental impact of wool carpet. When the sub-layer is not used, as is the case in Turkey and many other countries, the environmental impacts of wool carpet may be reduced.

In the developed model, the environmental impacts of the materials in the periods of raw material extraction and production are tested. However, to be able to make a sound decision in the selection of materials according to their environmental impacts, numerous criteria should be assessed, including the mode of manufacture, the layers, the distance between the raw materials and the place of manufacture, and the impacts on human health during their use. Furthermore, the useful life of a material, as well as the processes for maintenance and repair, also affect the assessment results as important criteria. A material with higher environmental impacts during manufacture may 
cause less environmental impacts than a more short-lived manufacture, but which requires maintenance, repair and alternative that has lower environmental impacts during renovation.

Table 3. Standard decision matrix [41]

\begin{tabular}{|c|c|c|c|c|c|c|c|c|}
\hline & $\mathrm{w}_{\mathrm{i}}$ & $\begin{array}{c}\text { Artificial } \\
\text { Marble }\end{array}$ & Linoleum & $\begin{array}{c}\text { Synthetic } \\
\text { Carpet }\end{array}$ & Mosaic & Ceramic & $\begin{array}{c}\text { Vinyl } \\
\text { Flooring }\end{array}$ & $\begin{array}{c}\text { Wool } \\
\text { Carpet }\end{array}$ \\
\hline Acidification & 0.1162 & 255.6692 & 76.0385 & 258.8938 & 120.5349 & 129.0296 & 63.6981 & 3348.7713 \\
\hline Air Pollutants & 0.1184 & 0.0674 & 0.016 & 0.0748 & 0.117 & 0.0357 & 0.0165 & 0.2324 \\
\hline Ecologic Toxicity & 0.1167 & 2.4722 & 0.9063 & 2.946 & 3.2877 & 0.9112 & 0.7174 & 14.4735 \\
\hline Eutrophication & 0.0569 & 0.1503 & 0.2447 & 0.5079 & 0.2132 & 0.0486 & 0.0239 & 7.5716 \\
\hline Fossil Fuel Depletion & 0.1167 & 0.6966 & 0.1466 & 0.776 & 0.3542 & 0.218 & 0.1395 & 0.6673 \\
\hline Global Warming & 0,0836 & 454.3336 & 116.4289 & 586.3363 & 294.0862 & 282.8182 & 121.7533 & 4382.2185 \\
\hline Human Health - Cancer & 0.0791 & 10.4342 & 0.0846 & 0.5777 & 0.8517 & 1.2201 & 0.0806 & 0.7333 \\
\hline Human Health - Noncancer & 0.1164 & 1249.7824 & 162.0475 & 854.6314 & 2078.8745 & 5144.4025 & 153.2529 & 2091.0156 \\
\hline Formation of Smog & 0.0657 & 3.4065 & 1.4362 & 3.2252 & 2.0799 & 1.3964 & 0.5621 & 52.7527 \\
\hline Water Intake & 0.0166 & 39.2789 & 24.428 & 16.8429 & 33.9895 & 0.3526 & 0.4491 & 22.7838 \\
\hline Ozon Depletion & 0 & 0 & 0 & 0 & 0 & 0 & 0 & 0 \\
\hline
\end{tabular}

Table 4. Sorting of materials by TOPSIS method [41]

\begin{tabular}{|c|c|c|c|c|c|c|}
\hline Materials & $\sum_{\mathrm{j}=1}^{\mathrm{n}}\left(\mathrm{v}_{\mathrm{ij}}-\mathrm{v}_{\mathrm{j}}^{*}\right)^{2}$ & $\sum_{\mathrm{j}=1}^{\mathrm{n}}\left(\mathrm{v}_{\mathrm{ij}}-\mathrm{v}_{\mathrm{j}}^{-}\right)^{2}$ & $\mathrm{~S}_{\mathrm{i}}^{*}$ & $\mathrm{~S}_{\mathrm{i}}^{-}$ & $\mathrm{C}_{\mathrm{i}}^{*}$ & $\begin{array}{c}\text { Item } \\
\text { No. }\end{array}$ \\
\hline Artificial Marble & 24942710538.7840 & 21179490938.5885 & 157932.6139 & 145531.7523 & 0.479568 & 3 \\
\hline Linoleum & 4834483.8932 & 128034312.0581 & 2198.7460 & 11315.2248 & 0.837298 & 2 \\
\hline Synthetic Carpet & 142286405.9473 & 4590623.2097 & 11928.3866 & 2142.5740 & 0.152269 & 7 \\
\hline Mosaic & 689684123.5463 & 198979153.5278 & 26261.8378 & 14105.9971 & 0.349437 & 6 \\
\hline Ceramic & 4216279322.5082 & 2768976954.7495 & 64932.8832 & 52621.0695 & 0.447633 & 5 \\
\hline Vinyl Flooring & 4277296.1899 & 130557955.7028 & 2068.1625 & 11426.1960 & 0.846739 & 1 \\
\hline Wool Carpet & 2919306106.1286 & 1943374483.8436 & 54030.3064 & 44083.7213 & 0.44931 & 4 \\
\hline
\end{tabular}

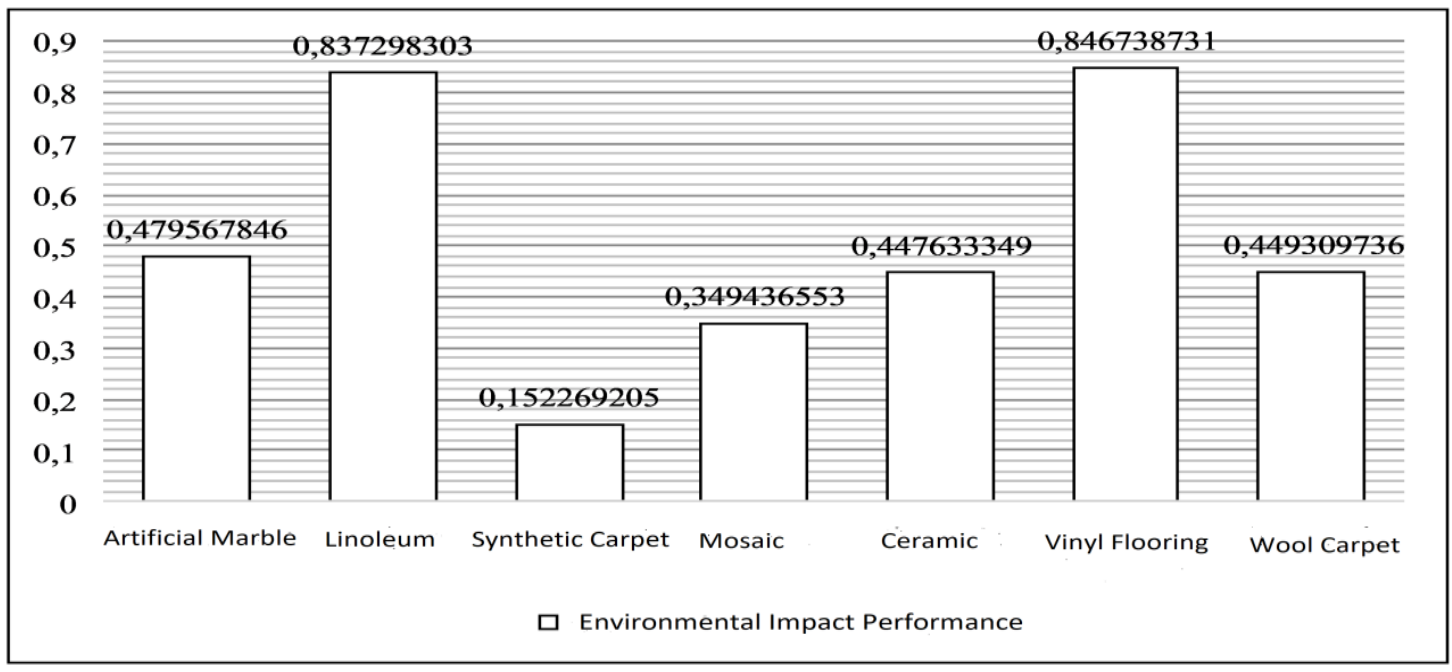

Figure 3. Environmental impact data of materials [41] 


\section{Conclusions}

The environmental performance of buildings should be assessed considering all phases of their life cycle, and the environmental impacts related to materials in the life cycle of buildings play an important role in the assessment of overall environmental performance. Architects should assess environmental impacts when selecting materials during the design phase of buildings. In this context, using a multiple-criteria decision-making method that is based on the model suggested in this study, an example material is selected from among the alternatives, considering the determined criteria. The flexibility of the developed model facilitates it to be used with different databases, and to consider different degrees of importance and other phases in the life cycle of a building.

The results obtained from this study cannot be considered fully accurate given that the materials in the database are not consistent with the materials available in Turkey, for which manufacturing methods are different. The characteristics of the local environment are undefined, and only the embodiment phase is taken into account, although this is not a limitation of the construction of the model, but the insufficiency of the data. In this regard, a local database should be developed, and the degrees of importance of the environmental impact classes in the local environment should be determined so that both the model and the calculation method specified in the standard [40] can be used. Water consumption will have a higher degree of importance in a country or region where water is scarce and will be assessed as a more important criterion in the selection of materials. Moreover, as the modes of manufacture of materials, production processes, characteristics and modes of transportation vary from country to country, and even from region to regions, their environmental impact data also varies. Hence, databases should contain data on the transportation of raw materials to the production facilities, and from the production facilities to places of production of materials. In this way, it can be determined scientifically whether the use of materials that have less environmental impacts during their manufacturing process but are far away from place of production, or local materials that have more environmental impacts during their manufacturing process but are closer to their place of production, would be more advantageous in terms of environmental impact. Additionally, the products of all producers of the same product should be detailed in the database, as otherwise, the performance assessment of buildings cannot be made thoroughly even if legal arrangements are made.

\section{REFERENCES}

[1] O. Kofoworola, S. Gheewala. Life cycle energy assessment of a typical office building in Thailand, Energy and Buildings, 41, 1076-1083, 2009.

[2] G. Verbeeck,H. Hens. Life cycle inventory of buildings, Building and Environment, 45 (4), 1037-1041, 2010.

[3] S. Chen, J. Wong. Variability of building environmental assessment tools on evaluating carbon emissions, Environmental Impact Assessment Review, 38, 132, 2013.

[4] F. Rey, E. Veloska, F. Varela. Building Energy Analysis (BEA): A Methodology to asses building energy labelling, Energy and Buildings, 39, 709-716, 2007.

[5] P. Hernandez, K. Burke, J. Lewis. Development of energy performance benchmarks and building energy ratings for non-domestic buildings: An example for Irish primary schools. Energy and Buildings, 40, 249-254, 2008.

[6] W. Lee. Benchmarking the energy efficiency of government buildings with data envelopment analysis, Energy and Buildings, 40, 891-895, 2008.

[7] X. Casals. Analysis of building energy regulation and certification in Europe: Their role, limitations and differences. Energy and Buildings, 38, 381-392, 2006.

[8] K. Govindan, K. M. Shankar, D. Kannan, D. Sustainable material selection for construction industry-A hybrid multi criteria decision making approach. Renewable and Sustainable Energy Reviews, 55, 1274-1288, 2016.

[9] J. C. Salcido, A. A. Raheem, S. Ravi. Comparison of embodied energy and environmental impact of alternative materials used in reticulated dome construction. Building and Environment, 96, 22-34, 2016.

[10] A. Koezjakov, D. Vorsatz, W. Crijns-Graus, M. Van Den Broek. The relationship between operational energy demand and embodied energy in Dutch residential buildings. Energy and Buildings, 233-245, 2018.

[11] M. K. Dixit, S. Singh, S. Embodied energy analysis of higher education buildings using an input-output-based hybrid method. Energy and Buildings, 161, 41-54, 2018.

[12] R. Zeng, A. Chini. A review of research on embodied energy of buildings using bibliometric analysis. Energy and Buildings, 172-184, 2017.

[13] B. Lawson. Towards ecologically sustainable development. Building Materials, Energy and Environment, Canberra, 1996.

[14] J. Kim, B. Ringdon. Sustainable architecture module: Introduction to sustainable design', National Pollution Prevention Center for Higher Education, 1998.

[15] R. H. Crawford. Life Cycle Assessment in the Built Environment. Spon Press, London, New York, 2011.

[16] A. Stephan, R. H. Crawford, K. Myttenaere. Towards a comprehensive life cycle energy analysis framework for residential buildings. Energy and Buildings, 55, 592-600, 2012.

[17] C Thormark. The effect of material choice on the total energy need and recycling potential of a building. Building and Environment, 41, 1019-1026, 2006.

[18] T. Y. Chen, J. Burnett, C. K. Chau. Analysis of embodied energy use in the residential building of Hong Kong. Energy, 26: 323-340, 2001. 
[19] N. Mithraratne, B. Vale. Life cycle analysis model for New Zealand houses. Building and Environment, 39, 483-492, 2004.

[20] N. Huberman, D. Pearlmutter. A life-cycle energy analysis of building materials in the Negev desert. Energy Build, 40, 837-848, 2008.

[21] M. Karimpou, M. Belusko, K. Xing, F. Bruno. Minimizing the life cycle energy of buildings: Review and analysis. Building and Environment, 73, 106-114, 2014.

[22] Y. G. Yohanis, B. Norton. Life-cycle operational and embodied energy for a generic single-storey office building in the UK, Energy, 27, 77-92, 2002.

[23] Y. Chang, R. J. Ries, Y. Wang. The embodied energy and environmental emissions of construction projects in China: An economic input-output LCA model, Energy Policy, 38, 6597-6603, 2010.

[24] D. Chwieduk. Towards sustainable energy buildings, Applied Energy, 76, 211-217, 2003.

[25] A. M. Moncaster, K. E. Symons. A method and tool for 'cradle to grave' embodied carbon and energy impacts of UK buildings in compliance with the new TC350 standards, Energy and Buildings, 66, 514-523, 2013.

[26] M. K. Dixit, J. L. Fernandez-Solis, C. H. Culp. System boundary for embodied energy in buildings: A conceptual model for definition, Renewable and Sustainable Energy Reviews, 21, 153-164, 2013.

[27] M. K. Dixit, J. L. Fernandez-Solis, S. Lavy, C. H. Culp. Identification of parameters for embodied energy measurement: a literature review, Energy and Buildings, 42(8), 1238-1247, 2010.

[28] M. K. Dixit, J. L. Fernandez-Solis, S. Lavy, C. H. Culp. Need for an embodied energy measurement protocol for buildings: A review paper, Renewable and Sustainable Energy Reviews, 16, 3730-3743, 2012.

[29] R. Johnston, P. Gogstad, J. Woolcock. Benchmarking and specification of sustainable building products, Envirospec, Sustainability UAE, 2008.

[30] A. Pears. Practical and policy issues in analysis of embodied energy and its application, Proceeding of the embodied energy: the current state of play seminar, 1996.

[31] S. Pullen. Data Quality of embodied energy methods, Proceedings of embodied energy seminar: current state of play, 1996.

[32] M. Raynolds, R. Fraser, D. Checkel. The relative mass-energy-economic (RMEE) method for system boundary selection, International Journal of Life Cycle Assessment, 5(1), 37-46, 2000.

[33] J. Fernandez. Materials and construction for low-energy buildings in China. Sustainable urban housing: principles and case studies for low-energy design in China. Springer, Dordrecht, The Netherlands, 2006.
[34] C. Atkinson. Life cycle embodied energy and carbon dioxide emissions in buildings. Industry and Environment, 19 (2), 29-31, 1996.

[35] H. Davies. Environmental benchmarking of Hong Kong buildings. Structural Survey, 19 (1), 38-46, 2001.

[36] W. C. Wan. Greening the materials for building and construction: Part 1. The contractor. Official Publication of the Singapore Contractors Association Limited (SCAL), 2008.

[37] A. Gültekin. A model proposal for assessing the environmental impacts of building products within the context of the life cycle assessment method. Doctorate Thesis, Gazi University Institute of Science and Technology, Ankara, 1-40, 2006. [Turkish]

[38] G. A. Blengini. Life cycle of buildings, demolition and recycling potential: A case study in Turin, Italy, Building and Environment, 44, 319-330, 2009.

[39] G. Blengini. The changing role of life cycle phases, subsystems and materials in the LCA of low energy buildings, Energy and Buildings, 42, 869-880, 2010.

[40] Turkish Standards Institute (TSE) (2012). Sustainability of building works - The method of assessment and calculation of the environmental performance of buildings. TS EN 15978, Ankara.

[41] O. Alptekin. Research Method in Construction Material Selection and A Model Proposal, Doctorate Thesis, Gazi University Institute of Science and Technology, Ankara, $1-80,2013$.

[42] Y. J. Lai, T. Y. Liu, C. L. Hwang. TOPSIS for MCDM. European Journal of Operational Research, 76, 486-500, 1994.

[43] International Organization of Standardization (ISO) (2006). Environmental management - life cycle assessment principles and framework, ISO 14040, Geneva, 1-20.

[44] ISO, (1998). Environmental management-life cycle assessment-goal and scope definition and inventory analysis, ISO 14041, Geneva, 1-16.

[45] ISO, (2003). Environmental management - life cycle impact assessment - examples of application of ISO 14042, ISO/TR 14047, 2003(E), Geneva, 1-87.

[46] ISO, (2000). Environmental management - life cycle assessment - life cycle interpretation, ISO 14043, Geneva, $1-18$.

[47] ISO, (2006). Environmental management - life cycle assessment - requirements and guidelines, ISO 14044, Geneva, 1-46.

[48] BEES Software, Life Cycle Assessment Software Guides, Online available from http://www.webcitation.org/ query?url=http $\% 3 \mathrm{~A} \% 2 \mathrm{~F} \% 2 \mathrm{Fwww}$.nist.gov $\% 2 \mathrm{Fel} \% 2 \mathrm{Feco}$ nomics\%2FBEESSoftware.cfm\%2F\&date=2014-04-29. 